Journal of Arts \& Communities, Special Edition Arts \& Human Rights in partnership with Amnesty

International

\title{
Memories of Violencia in the work of the Colombian artist Doris Salcedo: A subjective view
}

Beatriz Acevedo, Anglia Ruskin University

\begin{abstract}
The work of Colombian artist Doris Salcedo has become an important reference when talking about art and its representation of violence and exclusion. Following a tradition stemming from the artistic movements of the twentieth century, Salcedo has been acknowledged as one of the most intriguing and original artists in her exploration of public tragedy, the delicate issue of human rights and the trace of violence in those who are left behind. Salcedo's undertaking does not address those tangible manifestations of evil; instead, her work goes beyond the surface, inviting the spectator to a journey inside... into memories and feelings, into fears and intimate spaces. In this article, I offer a discussion regarding places, intersections and motivations in Salcedo's oeuvre and suggest some echoes between certain philosophical foundations of her work in relation to human rights in the case of Colombia. This article addresses the invitation for this Special Issue on Arts and Human Rights, focusing on the case of Colombia, where a systematic and ongoing crisis has damaged fundamental human rights for those affected by the civil conflict. In addition, as part of my work in management and organizational studies, I consider how Doris Salcedo's reflection is relevant to our understanding of labour and contemporary organizations.
\end{abstract}

\section{Keywords}


Journal of Arts \& Communities, Special Edition Arts \& Human Rights in partnership with Amnesty International

Colombia

Shibboleth

discrimination

Violencia

memory sculpture

Doris Salcedo

ethics

\section{Introduction}

The work of Colombian artist Doris Salcedo has become an important reference when talking about art and its representation of violence and exclusion. Following a tradition stemming from the artistic movements of the twentieth century, Salcedo has been acknowledged as one of the most intriguing and original artists in her exploration of public tragedy, the delicate issue of human rights and the trace of violence in those who are left behind. Salcedo's undertaking does not address those tangible manifestations of evil in its active harmful state; instead, her work goes beyond the surface, inviting the spectator to a journey inside... into memories and feelings, into fears and intimate spaces.

The latest exhibition by Salcedo at the Tate Modern in London called 'Shibboleth' (October 2007-April 2008) extends the artist's reflection on this topic by questioning western societies' attitudes towards discrimination, human rights and immigration. The title refers to an Old Testament story: 
Journal of Arts \& Communities, Special Edition Arts \& Human Rights in partnership with Amnesty International

The Book of Judges describes how the Ephraimites, attempting to flee across the river Jordan, were stopped by their enemies, The Gileadites. As their dialect did not include a 'sh' sound, those who could not say the word 'shibboleth' were captured and executed. Hence, therefore a shibboleth is a token of power: the power to judge, refuse and kill. (Herbert 2007)

This idea was materialized in the form of a crack, a sculpture of a fracture on the ground of the Turbine Hall at Tate Modern, crossing the 167 metres of this space. The work, carefully crafted to fit the massive space, creates a disturbing feeling of instability, and for many, it questions the very notion of art. Visitors to the exhibition had different reactions: some went along the gauge, others tried to cross it; some kept still and were puzzled, and a few tried to examine the interior of the fracture - woven in barbed wire. The artist explained that her work addresses and questions issues related to colonialism and postcolonialism, and certain operations of power. By calling this work 'Shibboleth', Salcedo aimed at provoking questions about personal, social, economic or cultural divisions. The leaflet provided by the Tate Modern also informs the spectator that 'Salcedo is addressing a long legacy of racism and colonialism that underlies the modern world. A shibboleth is a custom, phrase or use of language that acts as a test of belonging to a particular group or class'. With regard to conceptual art it is tempting to provide explanations or meanings, although perhaps it would be better to let the work speak for 
Journal of Arts \& Communities, Special Edition Arts \& Human Rights in partnership with Amnesty International

itself (O'Keeffe 2007). Indeed, this installation/sculpture is powerful because it works on many different conscious and unconscious levels.

The discussion about the artist's message in relation to shibboleth as a dispositif of power deserves a deeper analysis that is not addressed in this article. Instead, I offer a subjective account of Doris Salcedo's work, drawing upon my personal experience as a Colombian citizen and also as an academic living in the United Kingdom. I seek to explore some of the interrelationships between the violence in Colombia and contemporary concerns in western European societies. In this attempt, I do not wish to comment on the artistic value of Salcedo's work; instead, my purpose is to open a discussion regarding places, intersections and motivations in Salcedo's oeuvre and suggest some echoes between certain philosophical foundations of her work in relation to human rights in the case of Colombia. This article addresses the invitation for this Special Issue on Arts and Human Rights, focusing on the case of Colombia, where a systematic and ongoing crisis has damaged fundamental human rights for those affected by the civil conflict. In addition, as part of my work in management and organizational studies, I consider how Doris Salcedo's reflection is relevant to our understanding of labour and contemporary organizations.

\section{Memories}

Doris Salcedo was born in Bogotá (Colombia) in 1958. As for many of her generation, the ongoing Colombian violence has marked her life. The unsolved political conflicts of the 1950s, tragically labelled la Violencia, have been transformed throughout the 
Journal of Arts \& Communities, Special Edition Arts \& Human Rights in partnership with Amnesty International

subsequent decades into new forms of war fuelled by drug trafficking. The rooted social inequalities and the lack of economic opportunities have contributed to the exacerbation of crime and the growing power of illegal armies - guerrillas and paramilitaries - street gangs and criminal organizations - including drug trafficking cartels. On the international news, mafia vendettas, violent massacres, kidnapping and military operations seem to describe the daily life of Colombians. However, a traveler visiting Colombia would be surprised to find that cities such as Bogotá, Medellin or Cartagena exhibit a vibrant cultural and economic life, where people are prone to celebrating and dancing, as if oblivious to many tribulations announced in the news. In certain areas of these cities, the visitor will find shopping malls selling fashionable brands, as well as transport systems and public monuments that are presented by the locals as evidence of global progress. At the same time, the tourist will be advised to avoid certain parts of these cities: slums, poor neighborhoods or favelas, which nevertheless seem to hover close to the shining buildings and malls. The problem is that whereas a small portion of the population enjoys the benefits of 'progress', the majority of Colombians fall victim to poverty and its malaise. The work of Doris Salcedo has been focused on this 'other' part of the population: those displaced people wandering in the cities, the victims of the complex conflict who are only counted as figures for political campaigns, the witnesses of cruel abuses, all of those who are systematically ignored, avoided or forgotten by the mainstream society.

Several artists, including Miroslaw Balka, Rachel Whiteread and Doris Salcedo, have addressed the topic of memory in their artistic work. By using a particular type of 
Journal of Arts \& Communities, Special Edition Arts \& Human Rights in partnership with Amnesty International

sculpture, they aim at recalling certain events or memories through a material object through the involvement of the spectator and his or her emotions (Huyseen 1998, 2000; Cameron 1998). Huyseen (1998) has called this type of artwork 'memory sculpture'; he argues that by using discarded furniture, old garments or anodyne objects placed in certain spaces or within a particular architectural design, these artists succeed in triggering memories of previous presences and absences.

In these works, the material object is never just installation or sculpture in the traditional sense, but it is worked in such a way that it articulates memory as a displacing of past into present, offering a trace of a past that can be experienced and read by the viewer. (Huyseen 1998: 33)

This special meaning conferred to sculpture is at a distance from the western convention that links traditional sculpture with monuments. As analysed by Rosalind Krauss, during the twentieth century sculpture moved from traditional representation into an 'expanded field, defining itself initially in terms of "not architecture" and "not landscape". This kind of work 'was no longer organized around the definition of a given medium on ground of material or [...] the perception of the material' (Krauss 1986: 287). Rather, it entailed an intervention either in the architecture or by way of the marked site through a physical manipulation of sites in the landscape. In this way, sculpture is liberated of its monumental connotation and hence from its political or historical constraints: 
Journal of Arts \& Communities, Special Edition Arts \& Human Rights in partnership with Amnesty International

[This kind of work] no longer seeks representation of an event or place, but rather the loss or absence of an absolute referent. It does not claim as the monument had, to represent or to explain the truth of the past, of what happened. Rather it exposes itself to the distance then and now both in terms of the experience of that event and its recollection. (Merewether 1998: 16-17)

The message conveyed by this type of 'memory sculpture' does imply social and political concerns, and yet, it seems to acknowledge the limitations of representation. Salcedo's work, for example, addresses poignant realities of recent decades of the Colombian conflict. However, her work does not come across as an explicit protest, and it is not a monument to the victims of violence; nor does it involve blood, bullets or political slogans. Instead, Salcedo's sculpture stems from the interior of a room, the traces of a personal belonging or the uncanny familiarity of furniture in an abandoned house, revealing the fact that real people, perhaps happy families - now absent, displaced or murdered - once inhabited and used these ordinary places and objects. Her work thus becomes a form of 'counter-monument whereby representation, once provided consolation in the face of loss, becomes a metonym for a past or experience which is incommunicable, which is surrounded by silence, by a sense of absence, by the gaping holes of knowledge' (Merewether 1998: 17).

A brief review of some of her previous works illustrates her constant inquiring (of herself, of Colombians, of citizens around the world) about how violence leaves visible and invisible traces in the lives of both victims and survivors. This review also entails an 
Journal of Arts \& Communities, Special Edition Arts \& Human Rights in partnership with Amnesty

International

expedition into my own memories of events, feelings and questions that in the absence of a rational explanation may be expressed by the power of Salcedo's art. Through this journey - from Colombia to the United Kingdom - it will be possible to grasp some of the artist's concerns about migration, displacement, violence and memory expressed in her work at the Tate Modern as a continuation of her continuous questioning.

\section{Bearing witness}

Since the mid-1980s Doris Salcedo has sought to address the subject of conflict in Colombia. In her earliest works, she attempted to restage the site of violence, as memory and materiality. She collected disused hospital furniture such as trolleys, tables and bed frames. Placed against white walls and pushed into corners, these very same objects formerly associated with the clinical institution as a place of healing are transformed into a metaphor of violence; in this new space and configuration they appear as essential devices of a chamber of confinement or torture.

Salcedo's interest in how violence is exerted through institutions or architectural arrangements emerges from her reflection on the puzzling aftermath of the Colombian conflict during the 1980s. The intensification of the so-called guerra sucia/dirty war against left-wing movements and union leaders, the instauration of the 'disappearances', and the deployment of a paramilitary strategy against the rise of 'communism' have contributed to increasing the amount of abuses to human rights in the midst of the war. The artist thus turned her attention to these crises through intervening and transforming certain familiar objects: beds frames wrapped and bound like bandages over a wound, a 
Journal of Arts \& Communities, Special Edition Arts \& Human Rights in partnership with Amnesty International

baby's crib wrapped in barbed wire or household furniture buried in cement. In each of these works, the absent body was implied and the objects themselves became testimony to its passing (Merewether 1998).

Many of these sculptures were based on specific incidents. For example, the artist presented a sculpture made of white shirts, neatly folded, hardened with plaster and crossed with metal spikes. This sculpture refers specifically to massacres that occurred in 1988 at two agro-industrial plantations, called La Negra and La Honduras, committed by paramilitary groups. ${ }^{1}$ On 4 March 1998, twenty armed men in civilian clothes arrived at La Honduras farm situated in the jurisdiction of Turbo, in the Golfo de Urabá area of Colombia. They banged on the door of the room where the workers and their families were sleeping, and, calling each one by name, forced them to come out and lie down on the floor. Women, children and those workers who had not been selected were made to stay in their rooms and turn off the lights. The attackers then fired on the totally defenceless workers with short- and long-range weapons, killing the seventeen they had selected (Interamerican Commission on Human Rights 1993). Salcedo avoided a literal meaning, since the spikes did not show vital organs being pierced. Instead, the symbolism of this sculpture conveys the clean environment in which agro-industrial companies participate in the ongoing violence in Colombia. $^{2}$

During 1990-1991 Doris Salcedo exhibited Atrabiliarios/Defiant. This work consisted of a series of cavities made directly in the walls into which worn shoes were placed. The artist collected a quantity of old, worn shoes that had belonged to the 
Journal of Arts \& Communities, Special Edition Arts \& Human Rights in partnership with Amnesty International

desaparecidos/disappeared - people who have never been found. In particular, these garments belonged to women who 'disappeared' and were given to the artist by the victims' families. The shoes, which are only partially visible behind a screen made of animal skin, echo the presence of the women to whom they once belonged, whose fate and whereabouts are still unknown. Apart from functioning as portraits of the women 'disappeared', the works in the series also speak about the grief and uncertainty faced by those who were left behind.

Insert Figure 1: Atrabiliarios, 1990-1991. Image from The Legacy Project. Courtesy of Alexander and Bonin, New York. Photograph: Orcutt and Van Der Putten. Copyright: Doris Salcedo.

In a country such as Colombia where the anonymity of the victims seems to contribute to a culture of fear and silence, the public display of these humble objects is in itself a material clamour against indifference and forgetfulness.

The presentation of Atrabiliarios concerns not so much a refusal to present the scene or object of violence - a return to the scene of the crime - as much as giving visual form to the memory and, by doing so, bearing witness to a traumatic event for the first time. (Merewether 1998: 19)

Continuing her questioning of violent acts, Doris Salcedo developed Unland (1998). Unland is a created word, aiming to describe the situation of being 'displaced' from a 
Journal of Arts \& Communities, Special Edition Arts \& Human Rights in partnership with Amnesty International

territory, of being in no-land, invisible, forgotten, wandering across the country: a common consequence of the conflict in Colombia. During a period of three years, Salcedo spoke to children in orphanages and isolated towns in Colombia who had witnessed the murder of their parents. She collected pieces of furniture, tables, chairs, wardrobes, trying to extract their meaning in what once could have been a family, a house or a home. By assembling odd parts, by breaking the legs of an old table, or by weaving human hair or bone into these objects, the artist manages to show the distortions created by the violent acts and their impact in the lives of these children (Barson 2004).

Insert Figure 2: Unland, 1998. Image from Tate Enterprises. Copyright: Doris Salcedo.

However, the result expressed in the Unland sculptures does not attempt to provide a direct representation of these testimonies; nor does it try to convey the individual stories. In contrast, the artist produces an atmosphere, a feeling, an uncomfortable situation, in which these old pieces of furniture bear witness to the fragmentation and display the utter sadness of these experiences. As expressed by Barson (2004), 'the objects used in Salcedo's work are cut down, fragmented or otherwise mutated and recombined into forms that no longer have a use. They are deprived of their function in a way that is analogous to the dysfunction caused by extreme trauma'.

In one of the Unland sculptures called the Orphan's Tunic, Salcedo and her assistants drilled innumerable tiny holes into the surface of the old tables, through which they sewed hair and thread. This work is based on the artist's encounter with a 6-year-old girl 
Journal of Arts \& Communities, Special Edition Arts \& Human Rights in partnership with Amnesty International

who witnessed the killing of her parents. Each day of their encounter the girl wore the same dress, which, Salcedo discovered, had been made by her mother. Unable to speak about what happened, the child became attached to the dress as the last piece of her mother's presence. From a distance the woven hair in the tables seems almost imperceptible, but on close inspection it is possible to see the delicate weaving of hair and silk, as a reminder of the attachment of the girl to the fabric of her tunic. However, one may wonder, 'How are we to understand this combination of human hair and wood?'; art critic Andreas Huyseen offers a possible explanation:

Both are material residues from formerly living organisms, now arrested in their growth. The work plays on the contrast: the hair as fragile, thin, and vulnerable, with reminiscences of the famous piles of hair that we know from Holocaust photography, hair thus suggesting not life but death. The wood of the table, on the other hand, is solid, sturdy guarantor of stability. But just as the hair has been cut, the tables have been mutilated. (2000: 133)

By approaching the topic of violence through the display of these works in museums and galleries, Salcedo conveys the sensation of wasted life, of injustice and fear. She has referred to Hannah Arendt's writings about concentration camps. Arendt considered the camps as a location of crimes that were pernicious for all humanity, not just a certain group of people; to her they were crimes against the very status of mankind. Salcedo adopts this attitude in her commitment to these 'others' by questioning our own responsibility in historical events. She has focused on describing the extreme events in 
Journal of Arts \& Communities, Special Edition Arts \& Human Rights in partnership with Amnesty International

Colombian history, where life, meaning human life with full rights, not merely the basic condition of subsistence, is constantly threatened. Salcedo has said that 'the planet is full of these zones where we abandon people and anything can happen'.

Violence, unfortunately, is not limited to a single country. The same pain and similar tragedies can be found in Rwanda, Libya, Sarajevo, Syria, Georgia or in the streets of London, Paris or Rio de Janeiro. Nonetheless, in my experience, Colombians' memory is elusive and sometimes elastic. Colombians seem to suffer from an ongoing amnesia: the clamour over the latest celebrity scandal overtakes the grief of the most recent massacre. The task of remembering - no matter how sad or shameful these memories are - is part of Salcedo's notion of responsibility.

As did many of her previous works, her ephemeral sculpture Tenebrae Noviembre 6 and 71985 in 2002 compelled Colombians to recall the cruel events of that annus horribilis. This installation aimed to remember the siege of the Palace of Justice in 1985. Personally, that date marked a crucial moment of my life. I was just finishing secondary school and was looking forward to starting university life. On the morning of 6 November, some members of the urban guerrilla movement M-19 burst into the Palace of Justice in Bogotá. They demanded that President Belisario Betancur come to the Palace of Justice to stand trial - a symbolic way of 'judging' him for the failure of the peace process and social reforms. The government overreacted to the situation by refusing any negotiation; thus they decided to take the Palace by armed force. There is still confusion as to the exact details of the assault, specifically as to what happened inside. Many of the hostages 
Journal of Arts \& Communities, Special Edition Arts \& Human Rights in partnership with Amnesty International

died in the crossfire between the rebels and government forces. It is also believed that many of the hostages may have died when a group of government troops used explosives to enter the building via the rooftop; others argue that guerrilla started shooting hostages when they realized there was not going to be any negotiation. Whatever the explanation was, this siege caused the deaths of almost 100 people and the disappearance of several guerrilleros. The TV images of the day were almost unbelievable: armed tanks entering the gates of the Palace of Justice, violating the very symbol of justice in our country. Over the following days, the city was silent. The image of the building burning is still in my mind: the destruction of the streets, the curfew imposed by the military assault, the tenebrous smoke, the wound inflicted in the very heart of my beloved city...For Doris Salcedo, who at the time was near the scene and witnessed the attack, this event was crucial to her development as an artist. As she explained, it was the time when she wondered, 'what this means for me? How this affects my life? How can I go on eating, watching TV, walking, and living an apparent normal life, while knowing that this is happening?' (González 2008: 67).

Insert Figure 3: Palace of Justice Siege (Bogota, Colombia, November 1985). Photograph: Felipe Caicedo, Archivo El Tiempo.

Seventeen years later (2002) she addressed these questions with the ephemeral sculpture of the falling chairs called Tenebrae Noviembre 6 and 7 1985. The artist staged the 280 chairs that once were occupied by the magistrates who fell victim to the massacre. The 
Journal of Arts \& Communities, Special Edition Arts \& Human Rights in partnership with Amnesty International

first chair appeared suspended in the air at 11:35 a.m., the time when the first person was killed years ago, and the piece lasted as long as the actual duration of the massacre. The vision of 'falling chairs' appearing in the middle of the day in the heart of the city rang the bells of our memory... no matter how shining the new building of Justice may look, Salcedo's falling chairs aimed at impacting people in the street: those who remembered the tragic events and those who seem to forget that we still have a conflict to resolve.

Insert Figure 4: Tenebrae November 6 and 71985 (Installation). Copyright: Doris Salcedo. Photograph: Martin Garcia, Archivo El Tiempo.

For Colombians, the events of 6 and 7 November 1985 caused a number of collateral effects. Although twenty years later nobody has been held responsible for this tragedy and those who disappeared have never been found, the consequences for our society run as deep as an unhealed wound. By the 1990s the M-19 group had given up their arms, but the peace process became just a quick 'forget it all and move on'. Throughout that decade former members of left-wing guerrilla groups formed political parties - such as M-19, Esperanza Paz y Libertad (former members of the left-wing Popular Liberation Army) and Union Patriótica (ex-members of Revolutionary Army of Colombia). Unfortunately, their leaders were brutally assassinated by either right-wing extremists or drug trafficking gunmen. The siege of the Palace of Justice opened a huge wound in the collective mind; it was an assault on the very notion of Justice, and particularly for me - and for other Colombians of my generation - it was a huge blow to our faith either in the official government or in any other political option. It marked the end of dreams, the end of the 
Journal of Arts \& Communities, Special Edition Arts \& Human Rights in partnership with Amnesty

International

possibility of social change, and produced the silence and apathy that has became complicit in the violence and the perpetuation of the assault on human rights in our country.

Salcedo's work is silently poignant. In fact, her work defies a politics of redemption, and implies defiance in an even broader sense: defiance first of any direct representation of a self-perpetuating violence it would be too legitimizing to call political, and defiance also of an increasingly spectacularized culture of memory and its obsession with public sites of commemoration, monuments and memorials (Huyseen 2000: 119).

The installation by Salcedo and the effect of seeing the chairs falling from the roof of the new Palace of Justice conveyed the memories of our ongoing tragedy. The potential of art in moving spirits and conveying a human feeling is evident to me in this installation. Without words or political discourse, Salcedo stressed the necessity of preserving the memory of those who died in the siege of the Palace of Justice, and the responsibility of those who survived. Now, after eight years of living abroad, the question about responsibility came again with the exhibition of Doris Salcedo's Shibboleth at Tate Modern. This time the reflection goes beyond Colombian violence and addresses some of the hidden and evident conflicts in First World 'multicultural' societies.

\section{Shibboleth at Tate Modern (2007-2008)}

During the last seven years the Unilever Series at the Tate Modern has invited different artists to use the Turbine Hall as the setting for their works. The results have been 
Journal of Arts \& Communities, Special Edition Arts \& Human Rights in partnership with Amnesty International

memorable: the steel towers by Louise Bourgeois (2000), the memorable Weather Project (2003-2004) by Olafur Eliasson and the sound sculpture of Bruce Nauman's Raw Material (2004-2005), among others. In October 2007, the doors of the Turbine Hall opened to welcome the work of Doris Salcedo, the first Latin American artist to be commissioned to exhibit in this massive space. When entering the Tate Modern gallery, visitors received a leaflet advising caution when moving through the Turbine Hall. However, once you were inside, it was not very clear what the 'artwork' exhibited was, or why caution was required. In fact, an initial look inside the Turbine Hall showed no perceptible change: just that massive room, empty... and a small, almost imperceptible crack on the ground, which grew and deepened throughout the Hall.

Insert Figure 5: Shibboleth, 2007 at Tate Modern. Photograph: Beatriz Acevedo. Copyright: Doris Salcedo.

Salcedo explained,

Shibboleth is a negative space: it addresses the $\mathrm{w}($ hole) in history that marks the bottomless difference that separates whites from non-whites. The w(hole) in history that I am referring to is the history of racism, which runs parallel to the history of modernity and is its untold dark side. ${ }^{3}$

This reference to the inside, to the underground, to what is not necessarily evident (perhaps not publicly acknowledged) represented the first surprise for the spectator. We 
Journal of Arts \& Communities, Special Edition Arts \& Human Rights in partnership with Amnesty International

were compelled to look down, to watch inside, to wonder how or why this crack is opening. As the curator of this exhibition commented,

by choosing to go underground, the direction of the abject, rather than to reach up into the heights of the Turbine Hall with their promise of elevation, Salcedo implicitly challenges the lofty claims to beauty and truth that underpin much of the art on view on Bankside's upper floors, and instead reclaims a territory of those excluded from these unilateral ideals. (Borchardt-Hume 2007: 19)

A similar work representing a crack has been explored by the British artist Andy Goldsworthy, in his work titled Drawn Stone (2005). Commissioned by the Fine Arts Museum of San Francisco for the new de Young Museum, Goldsworthy proposed the creation of a crack running through the walkways and the courtyard of the museum. He was inspired by the geological constitution of the Californian landscape in the United States, its earthquakes and dynamic tectonic structure. Working with Appleton Greenmoore stone imported from Yorkshire (England), Goldsworthy aimed at bisecting two large rough-hewn stone boulders that would serve as seating for museum visitors. ${ }^{4}$

Although this is an important reference when analysing Salcedo's work at the Tate Modern, it is important to stress the differences between these two artists. First of all, the type of 'environmental art' produced by Goldsworthy aims at intervening the landscape by placing sculpture within the natural environment (Malpas 2003). In contrast, as a type of 'memory sculpture' Salcedo's work stems from the interior of a house or, as in this 
Journal of Arts \& Communities, Special Edition Arts \& Human Rights in partnership with Amnesty International

case, from the very centre of the Turbine Hall, and it is intended to trigger memories and feelings. The title of the work at the Tate Modern is also a crucial part for the interpretation of her work; thus, Shibboleth conveys a number of meanings and references that help to understand her message in relation to human rights. On the other hand, Goldsworthy's intention in using the materiality of a crack in Drawn Stone was to represent San Francisco's frequent earthquakes; hence the sculpture is situated outside the Museum, and he also added a functional characteristic to this work by creating benches for people to sit down.

In Shibboleth, Doris Salcedo utilized the museum as the scenario for critical awareness where the spectator is not necessarily invited to sit or to play with the crack. Indeed, for some the experience of the crack may represent exclusion, danger and instability. For the artist the fracture 'represents borders, the experience of immigrants, the experience of segregation, the experience of racial hatred. It is the experience of a Third World person coming into the heart of Europe' (BBC News, 2007).

My own experience in relation to the installation triggered certain feelings of alienation. As a foreign academic working in the United Kingdom it is difficult to describe exactly how discrimination works or how I have experienced it. Legislation and political correctness seem to neutralize the potential conflicts within organizations and social life. Nevertheless, the divisions are everywhere. From the first moment one steps into the country, the very structure of the airport defines limits: European nationals and British people in one side, and on the other, the rest... Frequently, returning from any journey 
Journal of Arts \& Communities, Special Edition Arts \& Human Rights in partnership with Amnesty International

abroad, I have had to endure long questioning on account of my Colombian passport. My nationality seems to carry a stigma (of drug trafficking, Third World, migrant, underdevelopment, poverty, violence), thus provoking the suspicious looks of not always very sympathetic officials.

Furthermore, the experience of 'difference' is also present in more institutional and organizational structures. For instance, when applying for different jobs I have had to fill numerous 'equal opportunities monitoring forms'. Every time I struggled to decide what 'ethnic background' to tick... yes, I am female, a bit white, but, I am not white British, not white other, and in fact, it is a mestizo colour, thus I had better tick 'mixed race'. Very often I chose to tick 'other', not always conscious of the ambivalence of the term and its implications.

I believe that Salcedo's work at the Tate Modern succeeded in providing a dramatization of the difference and the practices of exclusion and discrimination. The 'sacred' space of the museum or the gallery provides an unusual scenario for exposing the divisions that we - sometimes - rather ignore. Nonetheless, the divisions and the limits are ubiquitous: borders, lines, frontiers, institutional arrangements, architectural divisions, legislations, political slogans, all of them evidence of this process of 'discrimination'. At the dawn of the twenty-first century our main concerns are related to issues such as terrorism, religious fundamentalism and immigration. While the world is more connected and globalized, the differences are more visible. Barbed wire, frontiers, walls, checkpoints and other security measures exacerbate the divisions. As the critical geographer Derek 
Journal of Arts \& Communities, Special Edition Arts \& Human Rights in partnership with Amnesty International

Gregory (2004) has commented, the return of these colonial practices evidences a 'colonial present' - a world that is looking forward but moving backwards, culturally (seemingly) postcolonial but politically regressing into a new form of colonialism.

The materiality of Salcedo's work includes all these 'shibboleths': the wire fence embedded within the inner cuts of the crack, the instrument most associated with these colonial practices of separations, thus marking their return (Weizman 2007: 37). As the artist has stated, the fine line represented by the crack can be seen as the way in which migrants establish themselves in new territories. Beginning with a line, sometimes responding to an invitation to fulfill certain types of jobs, or simply because the conditions in their own countries push their labour force to find opportunities elsewhere, their presence begins to expand not only in numbers, but because they become more visible. In response, there is increasing legislation limiting immigration, restrictions to travellers, onerous charges for visas and an amazing amount of documents to prove your legitimacy.

The effect produced by the crack dividing the Turbine Hall in two halves, two worlds, two cities, two religions, points out the simplistic narratives of our leaders: 'with us or against us' (!). As argued by Bal,

the apparently empty space inside the crack, this 'nothing', includes everything that has disappeared into the abyss, like history, seen as willful amnesia and its aftermath; the 
Journal of Arts \& Communities, Special Edition Arts \& Human Rights in partnership with Amnesty International

history of the present in which history vanishes, leaves its scars only for those who care to see it, helped by the artist, who insists on showing the scar. (2007: 43)

The exhibition at the Tate Modern was disturbing; the crack does not imply immediate danger, yet it warns us about the cataclysms operating underground. The experience of Salcedo's Shibboleth and the process of writing this article have made me question my experience and responsibility at both sides of the fissure: as a subject of discriminatory practices and also as part of a wider mechanism that perpetuates differences and encourages exclusion. Being part of the higher education system, I wonder whether or not we are contributing to widening the gap, or whether there is a potential in education for bridging those differences. In this situation, one can ask about our responsibility as academics and scholars in organizational studies: Is it a matter of preaching 'equality', 'corporate social responsibility' or 'anti-discrimination practices'? Who must be accountable for that other: the organization, the legislation, justice courts and business lawyers? What are those shibboleths that we (at the personal level or within the organizational context) tend to create or replicate?

\section{Echoes}

As a scholar in management studies, I wonder how these reflections on human rights and discrimination are important for our area; indeed, the echoes, albeit imperceptible, become clearer. I will try then to draw some of these relationships as follows. First, I would like to recall the discussion about migrant labour force; second, the studies about discrimination; and third, the wider question about business ethics and social 
Journal of Arts \& Communities, Special Edition Arts \& Human Rights in partnership with Amnesty International

responsibility. Without attempting to present an expert discussion on these areas, I would like to comment briefly on them as a way of pointing out the relevance of the topics in Salcedo's work and the practice of business studies amongst scholars and researchers.

The first aspect is the ongoing discussion about migrant labour, and the challenges for organizations. As analysed by Castles (2000), migrant labour force can be understood as part of the processes of industrialization and capitalism. When the countries of post-war Europe embarked on their processes of reconstruction and industrialization, it was assumed that 'guest workers' from the underdeveloped areas of southern Europe or from the Third World would support the development of Europe's national economies. Only by bringing ever more workers into the production process can the capitalist accumulate capital, which is the precondition for extending production and applying new techniques (Castles 2000: 26).

However, apart from this economic function, the employment of immigrant workers has important socio-political purposes for capitalism: 'by creating a split between immigrant and indigenous workers along national and racial lines, and by offering better conditions and status to indigenous workers, it is possible to give large sections of the working class the consciousness of a labour aristocracy' (Castles 2000: 27).

In the United Kingdom, the phenomenon of a migrant labour force that nowadays take so much prevalence in debates on economy and society reflects these socio-political and economic functions (Pai 2004). However, collateral effects of these discussions are 
Journal of Arts \& Communities, Special Edition Arts \& Human Rights in partnership with Amnesty International

evidenced in the eruption of physical offences against migrants reported in newspapers across the country. This notwithstanding, less evident ways of discriminating and excluding appear in communities, organizations and towns across the country. Certain groups - such as non-white or non-British-born - although protected by the law and equal opportunities legislation, have to face 'racist' attitudes when entering certain industries or in their lives within other communities. Jokes, discrimination, exclusion and the isolation of certain areas of towns or cities are part of the mechanisms of racism. As noted by Balibar and Wallerstein (1991), it is common for racism to seek, to render inferior and to exploit minorities. The racism of inferiorization applies equally to modern situations of migrant labour: denial of rights forced western Europe's 'guest-workers' of the 1960s, or those coming during recent decades, to 'take jobs no one else wanted' (Castles 2000: 170). Regarding Doris Salcedo's social concerns, it is easy to find examples in British organizations of how challenging it can be to integrate or to achieve a multicultural society, and how on many occasions the shibboleths of exclusion replace those integrative promises made by managers or politicians.

A second reference within organizational and business studies involves certain practices of exclusion and discrimination. By drawing upon the work of Salcedo at Tate Modern, it is possible to say that shibboleths are not only 'sounds'; they can also be the different ways in which people are excluded, differentiated or separated. There are many examples at the organizational level of discriminatory practices. For instance, one of the most widely documented issues regarding organizational studies is the difficulty women face in progressing in their careers. There are issues not only of equal pay and the glass 
Journal of Arts \& Communities, Special Edition Arts \& Human Rights in partnership with Amnesty International

ceiling, but those other codes in which women's behaviour is systematically evaluated and proscribed (Brewis and Linstead 2000). Issues such as sexuality and femininity are regulated by organizations and co-workers, and by women themselves (Brewis 2005). Practices and beliefs regarding 'women-only' professions (i.e. nursing, catering or care) also reinforce the general perception that women 'should' occupy certain roles in the economic structure (Dempsey 2005).

A number of examples of discrimination based on race, sex, nationality, religion, disability or age can be found in newspapers and academic journals worldwide (Goldman et al. 2006). Although at the organizational level these problems may constitute a relatively minor concern, the problem becomes a gouging crack, similar to that represented by Salcedo, when cases in different companies, regions or sectors are added up. This problem goes beyond the individual practices or the organizational cultures. Indeed, what Salcedo proposes is to examine the question about 'responsibility', and in this sense she refers to the work of Philosopher Emanuel Levinas. From his philosophy she adopts the concept of responsibility for the other, which Levinas terms being-for-theother (rather than for the self). This idea is indebted to Dostoyevsky, whom Salcedo cites as a further influence: 'without responsibility an idea of community is impossible'. Salcedo's work conveys the idea of a common humanity, that every tragedy or death diminishes each one of us and all mankind must bear the ultimate responsibility (Barson 2004). 
Journal of Arts \& Communities, Special Edition Arts \& Human Rights in partnership with Amnesty International

Levinas' notion of responsibility stems from Heidegger's approach to the notion of 'being' beyond the 'ego' towards 'being in the world'. However, Levinas challenges the 'ontological' question by superposing an ethical quest; in other words, he asks about the Other as an inseparable part of the Being (Hand 1989). Levinas summarizes this fundamental point in an article entitled 'Beyond intentionality':

The sense of the human is not to be measured by presence, not even by selfpresence. The meaning of proximity exceeds the limits of ontology of human essence, and of the world. It signifies by way of transcendence and the relationship-to-God-in-me [the Infinite], which is the putting of myself into question.... The Infinite in its absolute difference withholds itself from presence in me $[\ldots]$ The Infinite is not indifferent to me. It is in calling me to other men that transcendence concerns me. In this unique intrigue of transcendence, the nonabsence of the Infinite is neither presence, nor re-presentation. Instead the idea of the Infinite is to be found in my responsibility for the Other. (1983: 112-13)

This view of the 'Other' in Levinas welcomes the artistic expression as part of a philosophical discourse, and Salcedo's work is clearly a response to the notion of human responsibility. When questioning similar topics in the field of organizational and business studies, it is possible then to consider Levinas' approach as a promising path in questioning the emerging topics of 'corporate social responsibility', 'business ethics' and 'corporate governance'. However, as Jones (2007) has noted, although Levinas' work has been widely discussed in the English-speaking world, it is only very recently that his 
Journal of Arts \& Communities, Special Edition Arts \& Human Rights in partnership with Amnesty International

views have been adopted in the discussion on organizational and management studies, particularly in the fields of business ethics (Jones 2003; Aasland 2004; Jones et al. 2005), corporate governance (Roberts 2001) and workplace surveillance (Introna 2003b). Recently, the interest in Levinas has produced a number of papers exploring his relevance for business ethics (Corvellec 2003; Introna 2003a, 2003b), leadership and organizational studies (Costea and Introna 2005; Rhodes and Westwood 2007). The relevance of Levinas in informing both scholarship and practice in business and organizational studies represents a formidable challenge and deserves further exploration.

\section{Questions}

Although the questions of exclusion and discrimination are present in our daily activities, it is remarkable how - at least in my personal case - these questions acquire a material expression through the experience of Salcedo's work at the Tate Modern. The impact of Salcedo's Shibboleth has touched me very deeply and this article has aimed to explore the many possibilities and ramifications of her message.

While writing this article many of my personal memories and experiences have come to the surface. Either in Colombia or in the United Kingdom, it is not difficult to see how the crack in our societies is growing. Distrust is ubiquitous in religions, languages, cultural codes, values, behaviours, etc. All are our contemporary shibboleths in that they reveal 'other groups' as distinctive, alien or different. These diverse tokens separate groups in our cities, as happens with tribes, cultures, neighbourhoods and postcodes. In 
Journal of Arts \& Communities, Special Edition Arts \& Human Rights in partnership with Amnesty International

Colombia, the polarization of the society and the labelling of those 'others' as 'terrorists, villains or bandits' are jeopardizing the possibility of a dialogue for a peace process. In the United Kingdom, the challenge is similar; nevertheless, way beyond the finding of a solution to the challenges of a 'multicultural' society in Britain, suspicion and fear are growing among the population. By representing this wound, Salcedo's art is committed to the representation of modern fears.

However, as the artist has remarked, her work aims at rescuing the sacred character of life, and thus her interest in preserving the collective memory, in pointing out the unhealed and dangerous wounds that from the underground are growing deeper: separating, excluding, discriminating. In Shibboleth, Doris Salcedo builds up different experiences originating from diverse parts of the planet, and hence her mastery is in bridging the different events into a universal consciousness, where human beings are responsible for each other, regardless of nationality, ethnicity or region, just because we are living beings.

Finally, Salcedo's frequent quotation of the famous line from Dostoyevsky's The Brothers Karamazov 'we are all responsible for everyone else - but I am more responsible than all the others' becomes relevant to start addressing similar questions in our communities, organizations or societies. In this exhibition as well as in her previous sculptures, the idea of a common humanity prevails and questions our own existence and responsibility, while opening a hopeful path for overcoming our contemporary shibboleths... 


\section{References}

Aasland, D. (2004), 'On the ethics behind "business ethics", Journal of Business Ethics, $53: 1$, pp. $3-8$.

Abbott, P. and Tyler, M. (1998), 'Chocs away: Weight watching in the contemporary airline industry', Sociology, 32:3, pp. 433-50.

Balibar, E. and Wallerstein, I. (eds) (1991), Race, Nation, and Class: Ambiguous Identities, London: Verso.

Barson, T. (2004), 'Unland. The place of testimony', Tate research papers, http://www.tate.org.uk/research/tateresearch/tatepapers/04spring/unland_paper.htm\#notes 20. Accessed 15 October 2008.

Bal, M. (2007), 'Earth aches: The aesthetics of the cut', in Tate Modern (Ed), The Unilever Series: Shibboleth, London: Tate Enterprises Publication, pp. 40-63.

Borchardt-Hume, A. (2007), 'Sculpting critical space', in Tate Modern (Ed), The Unilever Series: Shibboleth, London: Tate Enterprises Publication, pp. 12-21. 
Journal of Arts \& Communities, Special Edition Arts \& Human Rights in partnership with Amnesty International

Brewis, J. (2005), 'Signing my life away? Researching sex and organization', Organization, 12:4, pp. 493-510.

Brewis, J. and Linstead, S. (2000), Sex, Work and Sex Work, London: Routledge.

Cameron, D. (1998), 'Inconsolable', In Cameron, D. (Ed.) Doris Salcedo. New York: New Museum of Contemporary Art.

Castles, S. (2000), Ethnicity and Globalization: From Migrant Worker to Transnational Citizen, London: Sage.

Corvellec, R. (2003), 'The irreconcilability of corporate and managerial ethics'. paper presented at the Standing Conference for Organisational Symbolism, Cambridge, 9-12 July.

Costea, B. and Introna, L. (2005), 'Self and other in everyday existence: A mystery and not a problem', in A. Pullen and S. Linstead (eds), Organization and Identity, London: Routledge, pp. 60-85.

Dempsey, K. (2005), 'A woman's place is in the HR department', Personnel Today, 11 August, Business Source Premiere. Accessed 20 February 2008, p. 10-10. 
Journal of Arts \& Communities, Special Edition Arts \& Human Rights in partnership with Amnesty International

Elwert, G. (1999), 'Interventions in markets of violence', http://www.oei.fuberlin.de/en/projekte/cscca/downloads/ge pub_marketsofviolence.pdf. Accessed 24 September 2008.

Essed, P. (1991), Understanding Everyday Racism, Newbury Park, London and New Delhi: Sage.

Goldman, B., Gutek, B., Stein, J. and Lewis, K. (2006), 'Employment discrimination in organizations: Antecedents and consequences', Journal of Management, 32: 6 December, pp. $786-830$.

González, G. (2008), 'Doris Salcedo: A fracture in the heart of Europe'. Original title: 'Doris Salcedo y Shibboleth: Una Grieta en el Corazón de Europa', Revista Número, Edición 56, pp. 62-75

Gregory, D. (2004), The Colonial Present, Oxford: Blackwell, cited in Weizman, Eyal (2007), 'Seismic archaeology', The Unilever Series: Shibboleth, pp. 32-39.

Hand, S. (ed.) (1989), The Levinas Reader, Oxford: Basil Blackwell.

Herbert, M. (2007), The Unilever Series: Doris Salcedo, Shibboleth, Leaflet, London: Tate Modern. 
Journal of Arts \& Communities, Special Edition Arts \& Human Rights in partnership with Amnesty International

Huyseen, A. (1998), 'Sculpture, materiality and memory in the age of amnesia', in J. Bradley and A. Huyseen (eds), Displacements: Miroslaw Balka, Doris Salcedo, Rachel Whiteread. Toronto: Gallery of Ontario. Pp. 11-23

(2000), Doris Salcedo's Memory Sculpture. In Present Pasts: Urban Palimpsests and the Politics of Memory, E-book, Palo Alto, CA. Stanford University Press (Released 2003).

Interamerican Commission on Human Rights (1993), 'Annual report on Colombia', http:// http://www.cidh.org/annualrep/93eng/Colombia.10912.htm. Accessed 19 September 2008.

Introna, L. (2003a), 'The face and the interface: Thinking with Levinas on ethics and justice in an electronically mediated world', Working Paper 2003/092, Lancaster: Lancaster University Management School.

(2003b), 'Opinion: Workplace surveillance “is” unethical and unfair', Surveillance and Society, 1:2, pp. 210-16.

Jones, C. (2003), 'As if business ethics were possible "within such limits" ...', Organization, 10:2, pp. 223-48. (2007), 'Editorial introduction', Business Ethics: A European Review, 16:3, pp. $235-237$

Jones, C., Parker, M. and ten Bos, R. (2005), For Business Ethics, London: Routledge. 
Journal of Arts \& Communities, Special Edition Arts \& Human Rights in partnership with Amnesty International

Krauss, R. E. (1986), The Originality of the Avant-garde and Other Modernist Myths. Cambridge, MA: MIT Press,

Levinas, E. (1983), 'Beyond intentionality', in Alan Montefiore (ed.), Philosophy in

France Today, Cambridge: Cambridge University Press, pp. 112-13.

Malpas, W. (2003), Andy Goldsworthy in Close-Up, Maidstone, Kent: Crescent Moon.

Martin, J. (1994), 'The organization of exclusion: Institutionalization of sex inequality, gendered faculty jobs and gendered knowledge: Organizational theory and research', Organization, 1: 2, pp. 401-31.

Merewether, C. (1998), 'To bear witness', in D. Cameron (ed.), Doris Salcedo, New York:, New Museum of Contemporary Art.

O’Keeffe, A. (2007), 'Information overload: Conceptual art should be allowed to speak for itself', New Stateman, 22 October, pp. 42-43.

Pai, H. (2004), ‘An ethnography of global labour migration', Feminist Review, 77, pp. 129-36.

Roberts, J. (2001), 'Corporate governance and the ethics of narcissus', Business Ethics Quarterly, 11:1, pp. 109-27.

Rhodes, C. and Westwood, R. (2007), 'Letting knowledge go: Ethics and representations of the Other in international and cross-cultural management', in S. Clegg, C. Carter, M. 
Journal of Arts \& Communities, Special Edition Arts \& Human Rights in partnership with Amnesty International

Kornberger and M. Mesner (eds), Business Ethics as Practice: Representation, Discourse and Performance, Cheltenham: Edward Elgar, pp. 57-72.

Scott, Anna (2007), 'Firms need to "admit their own racism"”, People Management, 13:2, p. 14-14, Business Source Premiere. Accessed 20 February 2008.

Trade Union Congress (2007), 'The economies of migration', http://www.tuc.org.uk/extras/migration.pdf. Accessed 20 February 2008.

Weizman, E. (2007), 'Seismic archaeology', in Tate Modern (Ed.) The Unilever Series: Shibboleth, London: Tate Enterprises Publications, pp. 32-39.

BBC News (2007), 'A sculptor fills the Tate with a hole', 8 October, http://news.bbc.co.uk/2/hi/entertainment/7033619.stm. Accessed 24 September 2008.

Contributor details: Beatriz Acevedo is a lecturer in sustainable management at Lord Ashcroft International Business School at Anglia Ruskin University, Cambridge, United Kingdom. Her research interests concern the intersection between art, aesthetics and organizational studies. She also utilizes 'art' as a way of understanding complex social issues, such as the case of violence, discrimination, leadership, sustainability and conflict. Contact: Anglia Ruskin University. Lord Ashcroft Building. East Road. Cambridge, CB1 8PT. United Kingdom. Email: Beatriz.Acevedo@anglia.ac.uk 
Journal of Arts \& Communities, Special Edition Arts \& Human Rights in partnership with Amnesty International

Notes

${ }^{1}$ Paramilitary groups were created during the 1980 s by drug traffickers as private armies against left-wing guerrillas. Following the downfall of big cartels, such as Pablo Escobar's Cartel de Medellin or Cartel de Cali, paramilitaries took control of the drug trafficking business. However, as a recent article in The Guardian reveals, paramilitaries as right-wing organizations have aligned themselves with multinational interests. As claimed by the cited article, the leader of the paras, Carlos Castaño, was also an ardent supporter of neo-liberal economic policies and of multinational investment in Colombia so why should national and international companies not support them? In a newspaper interview, Castaño maintained there was always a reason for the paras' attacks: 'Trade unionists, for example. They stop the people from working. That's why we kill them' (see http://www.guardian.co.uk/world/2008/sep/20/colombia.cocacola, accessed 23 September 2008).

${ }^{2}$ This association is not something entirely new, as the massacre of the workers in the banana plantations for the United Fruit Company in the North of Colombia in 1928 demonstrates. The workers in the banana plantations in Colombia went on strike in December 1928. They demanded written contracts, eight-hour days, six-day weeks and the elimination of food coupons. The strike turned into the largest labour movement ever witnessed in the country until then. Troops were dispatched by the central government to deal with the strikers, who were labelled 'subversive'. The troops opened fire into the crowd of workers and their families. The images of 'wagons full of corpses' is described by Colombian writer Gabriel Garcia Marquez in his book One Hundred Years of 
Solitude. More recent events reveal that this practice is far from over. For example, the recent scandal of the multinational Chiquita has revealed that paramilitaries are on the payroll of the company, labelled 'security costs'. Further evidence of the existence of certain 'markets of violence' - defined by Elwert (1999) as the process by which unresolved conflicts become intertwined with neo-liberal dynamics and multinational interests is somehow revealed in Salcedo's work, thus providing a disturbing clairvoyance.

${ }^{3}$ Proposal for a project at the Turbine Hall, Tate Modern. By Doris Salcedo, December 2006.

${ }^{4}$ See de Young, Fine Arts Museums of San Francisco. Press Release: Fine Arts Museums of San Francisco Commission Works by Gerhard Richter, James Turrell and Andy Goldsworthy for New de Young Museum, 6 November 2004, http://www.famsf.org/fam/press/press.asp?presskey=171, accessed 29 July 2009. 